\title{
Essential Oils as a Potential Treatment Option for Pediculosis
}

Kerdalidec Candy ${ }^{1,2}$, Mohammad Akhoundi ${ }^{1}$, Valérie Andriantsoanirina ${ }^{1}$, Rémy Durand ${ }^{1}$, Christiane Bruel ${ }^{3}$, Arezki Izri $^{1,2}$

\author{
Authors \\ Affiliations \\ 1 Parasitology-Mycology Department, Avicenne Hospital, \\ AP-HP, Bobigny, France \\ 2 Unité des Virus Emergents (Aix-Marseille Univ - IRD 190 - \\ Inserm 1207 - IHU Méditerranée Infection), Marseille, \\ France \\ 3 Agence régionale de santé (ARS), Île-de-France, Paris, \\ France \\ Key words \\ pediculosis, Pediculidae, pthiridae, Pediculus humanus capitis, \\ Pediculus humanus humanus, Pthirus pubis, treatment, \\ eco-friendly pediculicides \\ received March 1, 2020 \\ revised April 3, 2020 \\ accepted April 11, 2020 \\ Bibliography \\ DOI https://doi.org/10.1055/a-1161-9189 \\ published online May 4, 2020 | Planta Med 2020; 86: 619- \\ 630 @ Georg Thieme Verlag KG Stuttgart · New York I \\ ISSN 0032-0943 \\ Correspondence \\ Mohammad Akhoundi \\ Parasitology-Mycology Department, \\ Avicenne Hospital, AP-HP \\ 125, route de Stalingrad, 93009 Bobigny cedex, France \\ Phone: + 33148955650 , Fax: + 33148955657 \\ m.akhoundi@yahoo.fr
}

\author{
Supporting information available online at \\ http://www.thieme-connect.de/products
}

\section{ABSTRACT}

Pediculosis is a prevalent ectoparasite infestation caused by lice. The head louse (Pediculus humanus capitis) and body louse (Pediculus humanus humanus) are obligatory parasites whose only known hosts are humans. Pediculosis is probably the most common ectoparasitic infestation, affecting up to $80 \%$ of the population in several countries, and particularly prevalent in the infant population worldwide. Several treatment options, including shampoos and creams containing insecticides, have been introduced for the treatment of pediculosis. Recently, the use of synthetic chemicals to control human lice has raised concerns pertaining to human health and the environment. Therefore, increasing efforts have been undertaken to develop effective pediculicides with low environmental toxicity and minimal environmental residual activity. In this study, we focus on the essential oils derived from 22 plant genera, their constituents, and the major factors that play important roles in the effectiveness of these oils in the treatment of pediculosis. Furthermore, we discuss the advantages and limitations of the mentioned essential oils, and ultimately suggest those demonstrating the most effective in vitro pediculicidal activities. The genera such as Aloysia, Cinnamomum, Eucalyptus, Eugenia, Lavandula, Melaleuca, Mentha, Myrcianthes, Origanum, Pimpinella, and Thymus appear to be more efficient against lice. These genera are rich in anethole, 1,8-cineole, cinnamaldehyde, p-cymene, eugenol, linalool, limonene, pulegone, terpinen-4-ol, and thymol compounds.

\section{Introduction}

Pediculosis is a widespread obligate ectoparasitic infestation caused by lice [1]. It is an important health problem with a global prevalence. Pediculosis is caused by two genera of blood-sucking lice: Pthirus and Pediculus. The genus Pthirus includes a single species, namely, Pthirus pubis (the pubic louse). The genus Pediculus consists of Pediculus humanus capitis (head lice) and Pediculus humanus humanus (body lice) (and one additional species in monkeys) subspecies, both of which are great concerns to public health [2]. P. humanus capitis is considered to be the causative agent of one-third of childhood infections, behind asthma and attention deficit disorder [3]. It is widespread globally and occurs across all ethnic groups as well as all socioeconomic levels $[4,5]$.
P. humanus humanus is common among socioeconomic groups such as the homeless, prisoners, and war refugees, which do not have ready access to standard conditions of hygiene. The body louse is considered to act as a vector of some pathogens such as Rickettsia prowazekii (epidemic typhus), Bartonella quintana (trench fever), and Borrelia recurrentis (relapsing fever) as well as Acinetobacter sp. [6].

Over the past 60 years, the treatment for pediculosis has relied mainly on the use of topical insecticides, including organochlorines (e.g., lindane introduced in 1960), organophosphorus (e.g., malathion in 1971), carbamates (e.g., carbaryl in 1977), and pyrethroids (e.g., permethrin in 1992) [7-11]. The persistent application of these chemicals has led to several reports of lice resistance from different countries such as the UK, France, and Denmark 
[12-14]. Hence, there is an urgent need to develop alternative approaches for louse management. Over the past decade, some novel compounds such as dimeticone, isopropyl myristate, and benzyl alcohol $[15,16]$, or neurotoxic compounds such as spinosad and ivermectin, were developed against louse species [17, 18]. Recently, natural products with pediculicidal properties, such as essential oils, have been used as therapeutic alternatives to the synthetic insecticides $[7,19,20]$.

Here, we present a detailed review of the relevant literature on essential oils with emphasis on their laboratory method of evaluation (in vitro), constituents, and the major factors influencing the efficiency of essential oils in the treatment of pediculosis. In addition, we also discuss the advantages and limitations of each group of essential oils in the treatment of pediculosis in detail, and ultimately suggest the groups that are the most effective against louse ectoparasites.

\section{Essential Oils}

Essential oils are blends of approximately 10 to 80 different metabolites extracted from plants through steam- or hydro-distillation [21]. Essential oils are commonly derived from plants belonging mainly to the families Myrtaceae, Lauraceae, Lamiaceae, and Asteraceae [22]. They are often extracted from various plant organs, such as flowers (e.g., Citrus bergamia), leaves (e.g., Citronella sp., Eucalyptus sp.), wood (e.g., Santalum sp.), roots (e.g., Chrysopogon zizanioides), rhizomes (e.g., Zingiber officinale), fruits (e.g., Pimpinella anisum), and seeds (e.g., Myristica fragrans) [22]. The compositions of essential oils are highly variable. They usually contain two or three major terpene or terpenoid components of low molecular weight, which often determine the biological properties of the essential oils [21]. They are biodegradable, with low environmental toxicity and minimal environmental residual activity due to being highly volatile, and are well accepted by people who want to discontinue the use of synthetic chemicals [22]. They have previously been reported to be highly effective in the treatment of pediculosis [23]. The potency of essential oils against lice varies considerably across species.

\section{Ex vivo pediculicidal activity of essential oils}

During the past few years, an increasing number of publications, including research articles, books, and media, pinpoint a rise in incidence of lice infestations and highlight the consequences of such infestations on the human health. To shed light on the past and present applications of essential oils against louse ectoparasites, a systematic review of the released literature, including research articles, books, and theses, was performed. Seven medical databases, including Scopus, PubMed, Science Direct, ProQuest, Web of Science, Springer, Medline, Embase, and Google Scholar, were explored with articles published from 1890 to 2019. The search strategy was performed using key words such as scientific species names as well as trivial names used for the lice and their corresponding genera and species, and also included various scientific thematic issues of research (biology, epidemiology, medical, control, etc.). The quest was performed using five languages (English, French, German, Portuguese, and Spanish). The relevant articles that met the aforementioned criteria were selected. Du- plicated articles, articles with unrelated topics and abstract, or with commercial publicity were excluded.

To evaluate the efficacy of essential oils against pediculosis, a database containing information on essential oils derived from 106 plant species belonging to 57 genera was gathered for this review. Then, the essential oils that have been demonstrated to be effective against the louse species are presented and discussed in detail in the subsequent sections. The names and characteristics of the major essential oils previously reported to be effective against louse ectoparasites are presented in $>$ Table 1.

\section{Lavandula}

The genus Lavandula consists of over 20 species that initially originated from the Mediterranean region and have varying growth habits, morphological characters, and chemical compositions. Three Lavandula species, namely Lavandula angustifolia (fine lavender), Lavandula latifolia (spike lavender), and Lavandula intermedia (lavandin), are mainly used to extract essential oils [24]. Lavender oils have been reported to possess antimicrobial, antifungal, and insecticidal properties [25]. Lavender oils have historically been recommended in the treatment of pediculosis [26,27] and reported to be effective, with a more than $80 \%$ knockdown effect against head lice in a laboratory study [28]. Furthermore, lavender and their components, such as linalool, are used as mosquito repellents [29]. Lavender oils are also effective against other insects and acari (e.g., Plutella xylostella, Dermanyssus gallinae, and Dermatophagoides spp.) [30]. The main constituents of lavender oil are linalool and linalyl acetate, concentrations of which may vary significantly across oils derived from different cultivars [25].

\section{Eucalyptus}

The genus Eucalyptus comprises about 900 species, of which over 300 species contain volatile essential oils in their leaves [31]. They were originally native to Australia and have been cultivated worldwide for industrial and medicinal purposes. The essential oils of some Eucalyptus species (e.g., Eucalyptus globulus) exhibited high activity against head lice [32,33]. In addition, other species of Eucalyptus, including Eucalyptus sideroxylon, Eucalyptus cinerea, Eucalyptus viminalis, Eucalyptus saligna, Eucalyptus grandis, and Eucalyptus camaldulensis or their hybrids, were also reported to have significant pediculicidal effects against head lice [34]. Furthermore, the oils extracted from some Eucalyptus species (e.g., Eucalyptus citriodora) have been used as insect repellents [35]. Overall, Eucalyptus species found to be effective against head lice have a high content of 1,8-cineole as the main component [ 34 , 36].

\section{Cinnamomum}

The genus Cinnamomum comprises about 250 species. Two wellknown species of this genus are Cinnamomum zeylanicum and Cinnamomum cassia [37]. They have antioxidant, anti-inflammatory, antidiabetic, antimicrobial, and anticancer properties [37]. Essential oil from the bark/leaf of C. zeylanicum significantly inhibited the adults as well as eggs of $P$. humanus capitis $[38,39]$. Other species of Cinnamomum, including C. cassia and Cinnamomum porphyrium, have also been reported to kill head lice [40]. In addition, Cinnamomum species can repel or kill a variety of insects, includ- 


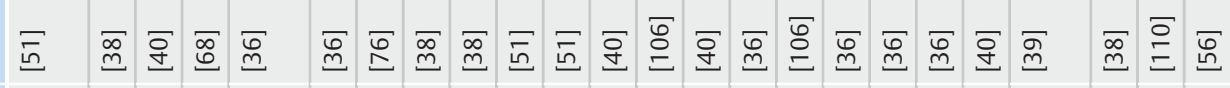

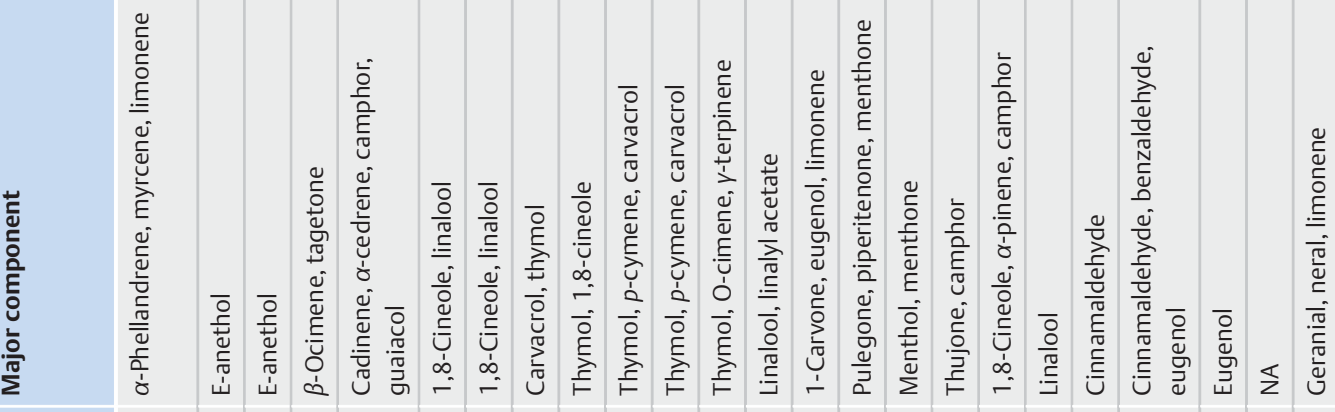

产

욤

$\therefore \stackrel{\substack{\infty \\ \infty}}{\infty}$

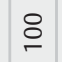

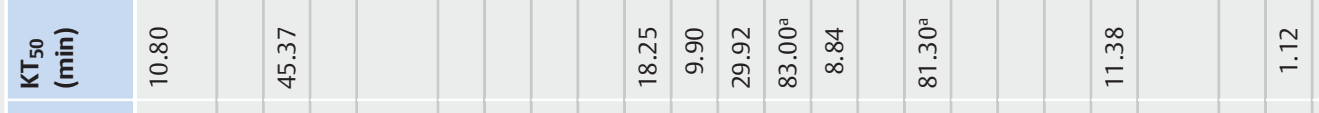

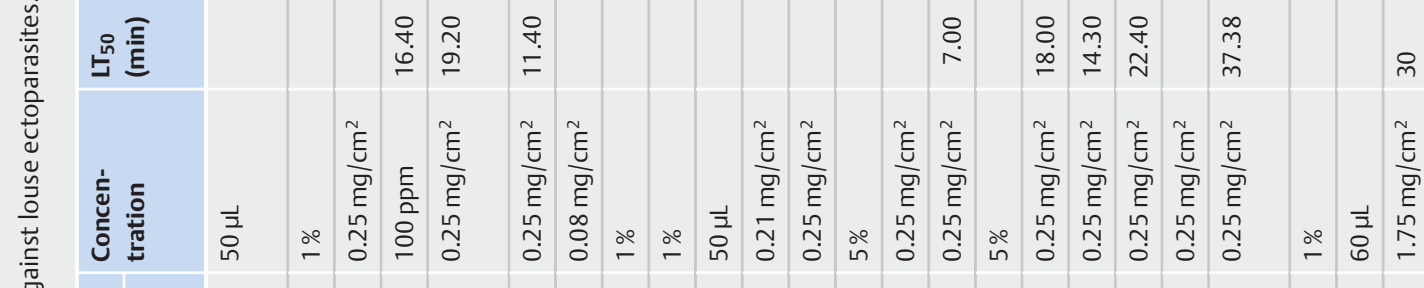

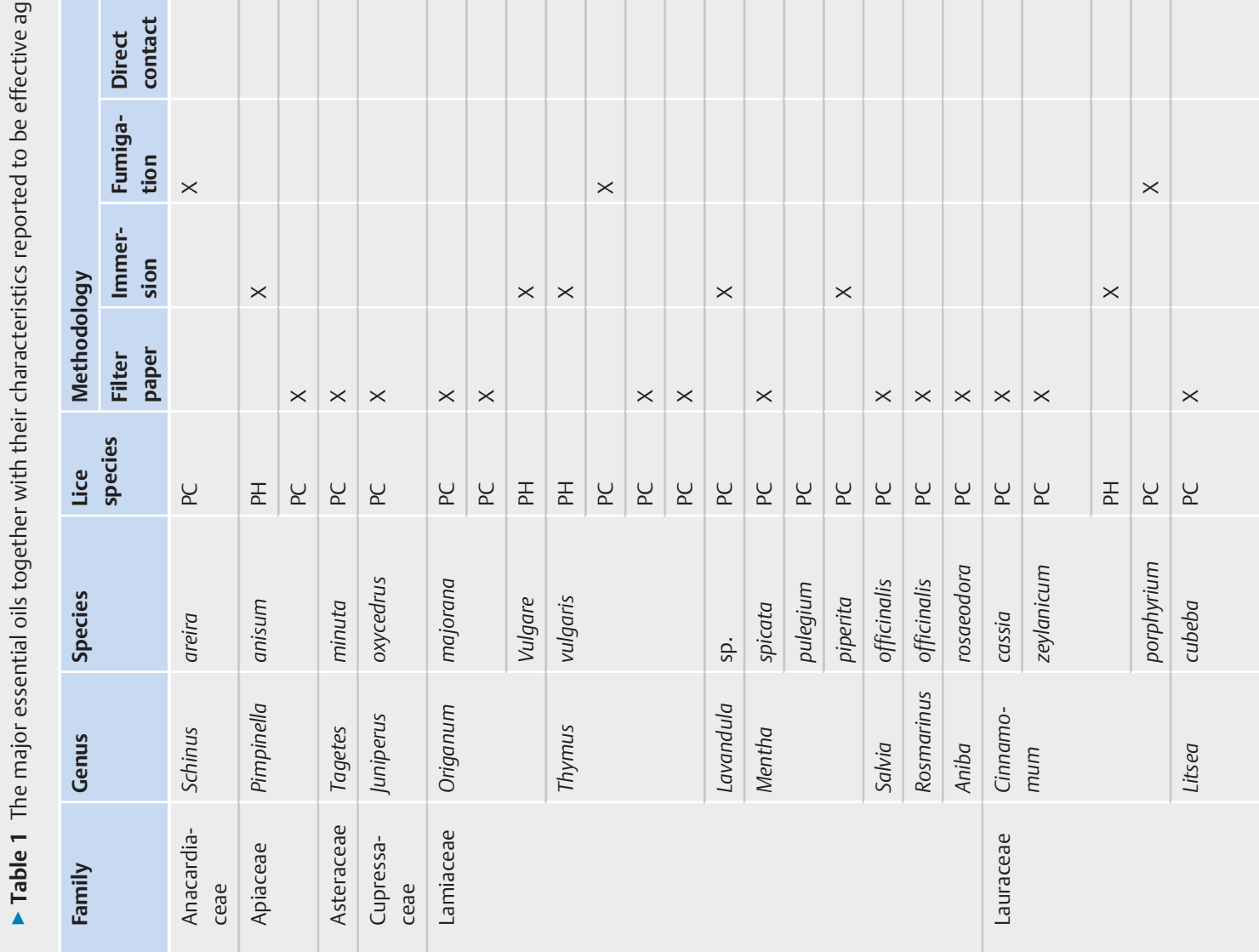



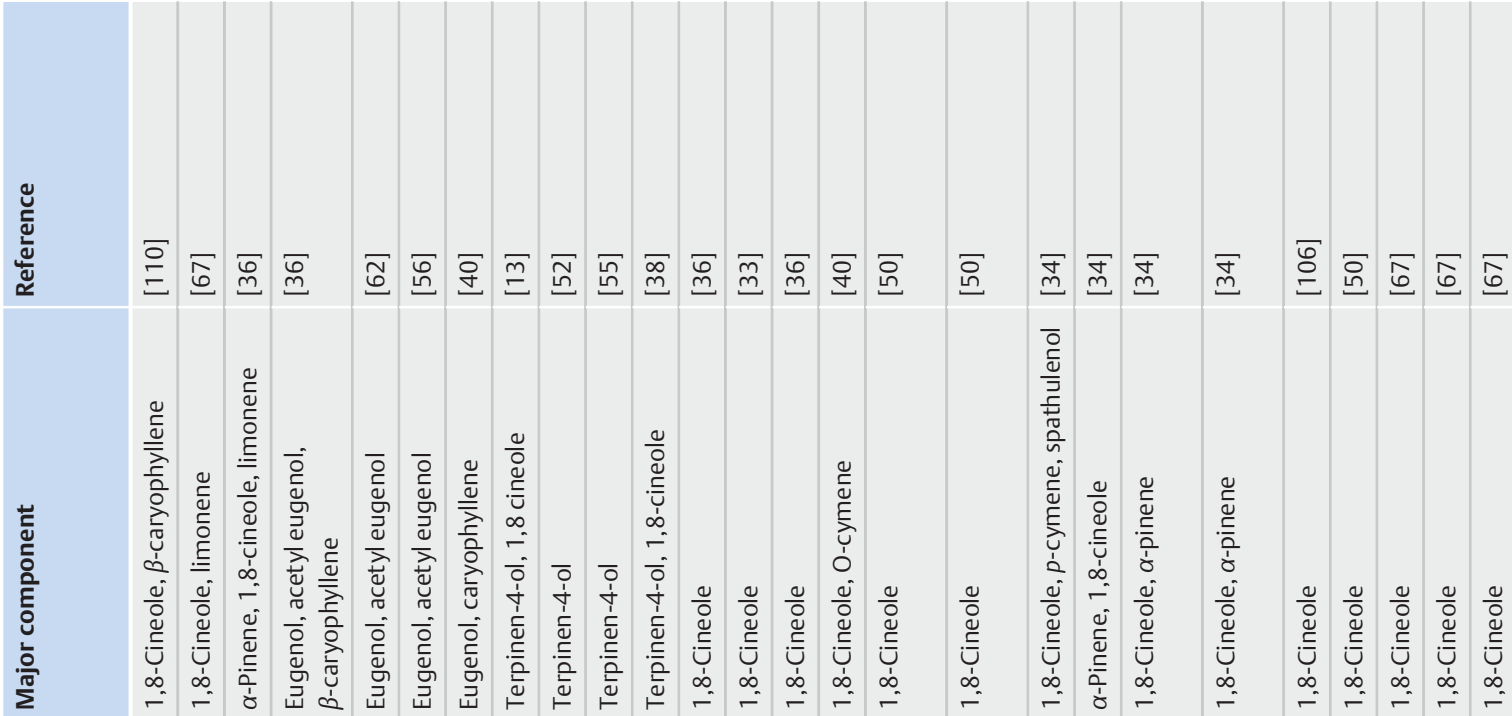

裹变

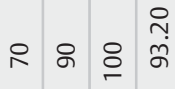

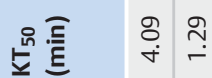

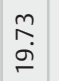

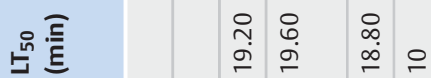

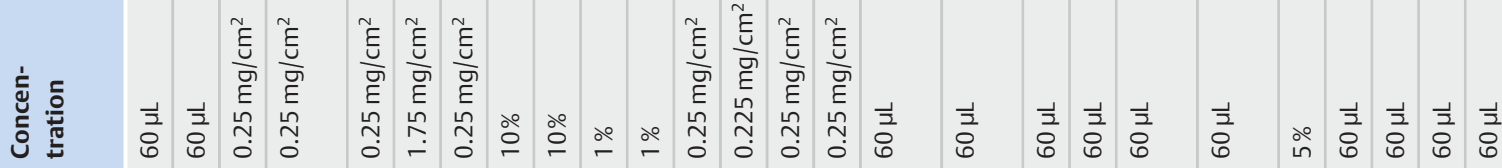

芯芯

宛

돈 $\stackrel{0}{\frac{5}{}} \times \times$

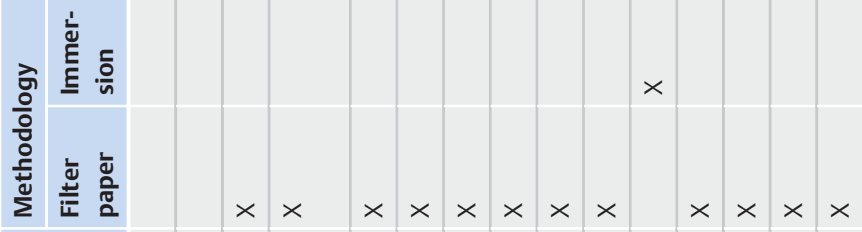

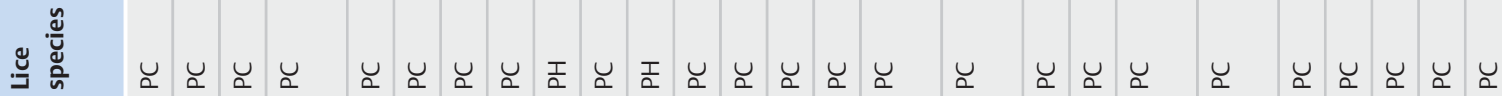

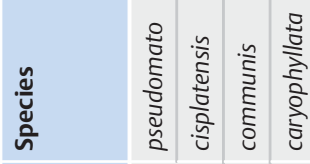

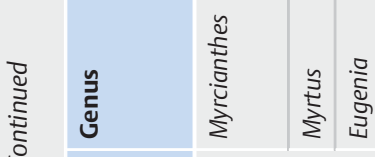

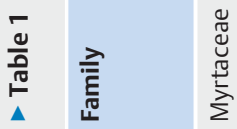

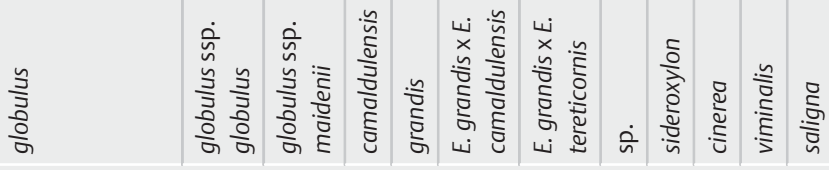

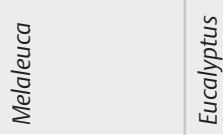




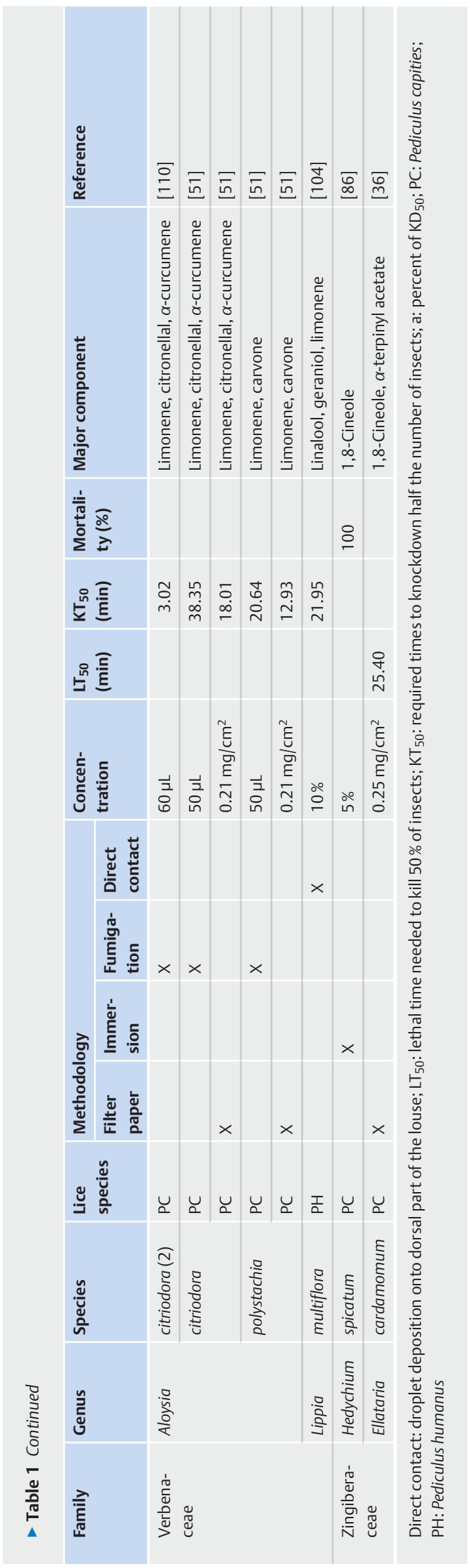

ing Anopheles gambiae and Plodia interpunctella [29,41]. The main components of Cinnamomum species are cinnamaldehyde, benzaldehyde, and eugenol [39].

\section{Mentha}

The genus Mentha has a cosmopolitan distribution and comprises a large number of species, including Mentha piperata (peppermint), Mentha spicata (spearmint), and Mentha pulegium (pennyroyal). Essential oils extracted from the leaves of Mentha species have been studied for their activity against gastrointestinal disorders as well as for their anti-inflammatory properties [42]. These species have also been reported to inhibit head lice $[28,36]$. Moreover, they have repellent and insecticidal/acaricidal activities against mosquitoes, Ixodes ricinus, and Dermatophagoides spp. $[43,44]$. The compositions of these essential oils are highly variable, and the main components include menthol, menthone, carvone, pulegone, piperitenone, and limonene ( $\bullet$ Table 1) [45].

\section{Aloysia}

The genus Aloysia comprises about 30 species that are generally known as "bee brushes". They are native to the Americas, where they are distributed in temperate and subtropical climates. Essential oils extracted from Aloysia species have been studied for their anti-oxidant, antimicrobial, and anti-inflammatory properties [46]. Furthermore, they also inhibit Leishmania parasites (e.g., Leishmania amazonensis) and insects (e.g., Culex quinquefasciatus and Nezara viridula) [47-49]. Some Aloysia species such as Aloysia polystachya and Aloysia citriodora have been demonstrated to be effective against head lice $[50,51]$. The major components of Aloysia species are limonene, carvone, citronellal, and $\alpha$-curcumene [51].

\section{Melaleuca}

Melaleuca alternifolia, belonging to the plant family Myrtaceae, is native to Australia and a source of tea tree essential oil. Tea tree oil is reported to have a wide variety of biological properties, including antimicrobial, anti-inflammatory, and acaricidal activities $[52,53]$. Tea tree oil was reported to be potentially effective against both head and body lice $[52,54,55]$. The main components of $M$. alternifolia are terpinen-4-ol, $\gamma$-terpinene, $\alpha$-terpinene, and $\alpha$-terpineol [56].

\section{Pimpinella}

The genus Pimpinella includes herbaceous plants, of which Pimpinella anisum, the most popular condiment plant species, is cultivated worldwide for its aromatic seeds (aniseeds) [57]. Anis seeds have digestive and antimicrobial properties and inhibit insects, including Culex pipiens and Lucilia sericata [58-60]. Moreover, P. anisum was found to be effective against both head and body lice $[34,36]$. The most important component of aniseed essential oil is trans-anethole [40].

\section{Eugenia}

Eugenia is an evergreen tropical plant genus comprising about 1000 species. The most economically important species of this genus is Eugenia caryophyllata (Syzygium aromaticum). The dried flower of clove is a popular kitchen spice used in both food and 
medicine (anesthetic, analgesic, antimicrobial, antioxidant, antiinflammatory, and anticancer agents) [61]. E. caryophyllata (clove oil) was reported to display high pediculicidal activity against head lice $[40,56]$, which was comparable to that of commercial insecticides $d$-phenothrin and pyrethrum [62]. In addition, clove oil and its major component (eugenol) have repellant, acaricidal, and insecticidal activities (against Aedes and Anopheles mosquitoes, D. gallinae, and Sarcoptes scabiei) $[29,63]$. The major component of clove oil is eugenol, followed by acetyl eugenol and $\beta$-caryophyllene [56, 62].

\section{Schinus}

The genus Schinus includes 25 species native to Central and South America [64]. They possess antioxidant, antimicrobial [65], and insecticidal [66] properties. Essential oils extracted from the leaves and fruits of Schinus areira were found to be effective against head lice [51]. The dominant compounds found in leaf essential oils of $S$. areira were monoterpene hydrocarbons, namely, $\alpha$-pinene, $\beta$-pinene, camphene, and $\alpha$-phellandrene $[51,67]$.

\section{Tagetes}

Tagetes is a genus of herbaceous plants comprising 30 species, some of which are cultivated for ornamental or medicinal purposes (e.g., Tagetes erecta, Tagetes minuta or Tagetes glandulifera, Tagetes patula, and Tagetes tenuifolia). Some species such as $T$. minuta were found to have significant pediculicidal activity against head lice [68]. Tagetes plants also repel or kill a wide range of insects such as mosquitoes (Aedes and Anopheles), Phlebotomus duboscqi, Cimex lectularius, Ceratitis capitata, and Triatoma infestans [69-71]. Major components of $T$. minuta are beta-ocimene and tagetone [72].

\section{Juniperus}

The genus Juniperus, which is widely distributed in the northern hemisphere, is a well-known source of cedarwood oil. It is used in traditional medicine due to its antiseptic, neuroprotective, and anti-inflammatory properties [73]. Furthermore, it also has antileishmanial [74] and acaricidal (e.g., Dermatophagoides farinae) activities [75]. Some species such as Juniperus oxycedrus were found to be effective against head lice [36]. The main components of $J$. oxycedrus are cadinene, $\alpha$-cedrene, camphor, and guaiacol [75].

\section{Origanum}

Origanum is a genus of perennial herbs native to Europe, North Africa, and most of temperate Asia. This genus includes important groups of culinary herbs, including marjoram (Origanum majorana) and oregano (Origanum vulgare). These species are also effective against head lice $[38,76]$. In addition, they have antibacterial and antifungal properties. They also display activity against hematophagous mosquitoes (Aedes, Culex, and Anopheles) [77,78], I. ricinus [43], and Psoroptes cuniculi [79]. The main components of Origanum species are 1,8-cineole, linalool, and carvacrol [67, 76].

\section{Thymus}

The genus Thymus comprises 350 species of aromatic perennial culinary herbs native to the temperate regions of Europe, North Africa, and Asia. Thymus species have antioxidant and antibacterial properties as well as insecticidal/acaricidal activities against Tetranychus urticae, Blatta lateralis, and mosquitoes (Culex, Aedes, and Anopheles) [80-83]. Among Thymus species, Thymus vulgaris has been found to be effective against both head and body lice [ 40 , 51]. The major constituents of Thymus species are thymol, carvacrol, and p-cymene [40,51].

\section{Hedychium}

The genus Hedychium consists of about 80 perennial herbaceous species characterized by scented flowers. Hedychium spicatum (spiked ginger lily), which originated in the southeast Asian countries, is a widely known species of this genus [84]. Hedychium species have been reported to possess antibacterial, antifungal, and anthelmintic activities $[84,85]$. $H$. spicatum possesses strong pediculicidal activity against head lice [86]. Its major component is 1,8-cineole.

\section{Elettaria}

Elettaria is a genus of plants native to India and Sri Lanka. The essential oil derived from Elettaria cardamomum (cardamom oil) is reported to be effective against head lice [32]. It is also active against $D$. gallinae [87]. Its major components are 1,8-cineole and $\alpha$-terpinyl acetate [88].

\section{Salvia}

The genus Salvia comprises roughly 1000 species that have been demonstrated to possess significant antitumor [89], antiprotozoal [90], and insecticidal activities against Anopheles, Aedes, and Culex mosquitoes [91]. Some species, such as Salvia officinalis (sage), were reported to be effective against head lice [32]. The main components of $S$. officinalis are $\alpha$-thujone, camphor, 1,8 -cineole, and $\beta$-thujone.

\section{Rosmarinus}

The genus Rosmarinus includes perennial culinary herbs native to the Mediterranean basin. Rosmarinus species possess antioxidant, antibacterial, and antileishmanial properties [92]. Rosmarinus officinalis has been demonstrated to be effective against head lice [32]. In addition, it is effective against $I$. ricinus and mosquitoes [93]. The major components of $R$. officinalis are 1,8-cineole, $\alpha$ pinene, and camphor [38, 92].

\section{Aniba}

Aniba is a genus of plants native to the Brazilian Amazon. It comprises 41 species, including Aniba rosaeodora, which have been reported to have sedative, antiviral, anticonvulsant, and antidepressant activities $[94,95]$. A. rosaeodora has been reported to be highly effective against head lice [32]. Linalool has been identified as its major constituent [95].

\section{Litsea}

The genus Litsea comprises approximately 200 plant species that are mainly distributed in the tropical and subtropical regions [93]. 
Litsea species have been reported to display anti-inflammatory, antibacterial, antifungal [96,97], and repellent/insecticidal activities $[98,99]$. Recently, an essential oil derived from the fruits of Litsea cubeba was reported to be effective against head lice [56]. Its main components are citral (geranial, neral, and limonene) [56].

\section{Myrcianthes}

Myrcianthes is a genus of plants native to Central and South America as well as west India. Myrcianthes species have been reported to have antimicrobial, antiviral, and insecticidal properties [100, 101]. Among Myrcianthes species, Myrcianthes pseudomato and Myrcianthes cisplatensis have been found to be effective against head lice [67]. The main components of $M$. ciplatensis are limonene, 1,8-cineole, and $\alpha$-terpineol [67], whereas those of M. pseudomato are 1,8-cineole and $\beta$-caryophyllene [100].

\section{Myrtus}

The genus Myrtus comprises two species, namely, Myrtus nivellei and Myrtus communis. The latter is an evergreen shrub native to the Mediterranean littoral region, utilized for its antiseptic, antiinflammatory, anti-plasmodial, and insecticidal activities against C. pipiens and A. gambiae $[102,103]$. It is also effective against head lice [32]. The main components of $M$. communis are $\alpha$ pinene, 1,8-cineole, and limonene [102].

\section{Lippia}

Lippia is a genus of flowering plants including 200 species of which Lippia multiflora has been reported to have antimicrobial, antimalarial, and scabicidal properties $[104,105]$. In addition, it has been reported to be effective against both head and body lice [104]. The main components of L. multiflora are limonene, geraniol, and linalool [104].

Apart from the aforementioned genera, several other essential oils have been assessed against louse ectoparasites and have been reported to be ineffective. A list of essential oils ineffective against lice is presented in Table 1S, Supporting Information.

\section{Key Factors Influencing the Pediculicidal Activity of Essential Oils}

The pediculicidal potential of essential oils against lice species may vary significantly depending on intrinsic and extrinsic factors such as the method of evaluation used and the chemical composition.

\section{Method of evaluation}

Essential oils are assessed mainly by four different methods. The most frequently used methods for the assessment of essential oils are impregnated filter paper contact and fumigation.

Filter paper contact: This method involves impregnating a filter paper placed at the bottom of a petri dish with a given concentration of the essential oil. Then, the lice are placed inside the petri dish and the mortality parameters such as $\mathrm{LT}_{50}$ (time needed to kill $50 \%$ of the insects) or $\mathrm{KT}_{50}$ (time required to knock down
$50 \%$ of the insects) are recorded at the end of the contact time $[39,40,56]$.

Immersion: In this method, lice are dipped in the essential oil solution for a predetermined period of time (seconds to minutes) and then the knockdown or mortality rate is recorded $[38,106]$.

Fumigation: This method uses a closed fumigation chamber (petri dish) containing a microslide on which drops of essential oil and the lice are placed separately. Consequently, the lice are exposed to vapors from the oil [67]. In another variant of this technique, called "vapor phase toxicity", a fine voile sieve is used to prevent the direct contact of lice with the paper impregnated with essential oil $[36,51]$.

Direct contact: This involves depositing the measured oil drops directly on the dorsal part of the louse body [107]. Then, LC $_{50}$ (concentration sufficient to kill $50 \%$ of the lice) or $\mathrm{KT}_{50}$ are calculated at the end of the experiment $[104,107]$.

In addition to the aforementioned methods, the factors of contact time, concentration, and solvent type are crucial in determining the efficiency of the essential oil against louse ectoparasites.

Contact time: Contact time is one of the factors influencing the efficacy of essential oils and varies according to the applied method. Moreover, the contact time varies between different assays within the same method. In the immersion bioassay, immersion time ranges from $10 \mathrm{~s}$ to $2 \mathrm{~min}[38,106]$. In the filter paper contact method, some investigators set the contact time at 1530 min $[55,56]$, while others place the lice on impregnated filter papers throughout the experiment ( $1-5 \mathrm{~h}$ ) [39]. Similarly, in a fumigation test, lice are placed inside a petri dish chamber throughout the time of observation ( $\sim \mathrm{h}$ ) [67]. Longer time of exposure might influence the efficacy of the essential oil. As an example, the mortality rate of body lice exposed to tea tree essential oil for 30 to $210 \mathrm{~min}$ is increased from 10 to $90 \%$ [52].

Concentration: The concentrations of essential oils vary widely depending on the method used. For filter paper contact, the concentrations range from $0.21 \mathrm{mg} / \mathrm{cm}^{2}$ to $1.75 \mathrm{mg} / \mathrm{cm}^{2} ; 1-10 \%$ for both direct contact and immersion assays and 50-60 $\mu \mathrm{L}$ for the fumigation assay. This variation can lead to differences in the efficacy of the oils ( $\bullet$ Table 1 ). Using the filter paper contact assay, Candy et al. [56] observed that essential oil from E. caryophyllata at a concentration of $1.75 \mathrm{mg} / \mathrm{cm}^{2}$ could kill head lice almost two times faster ( $\mathrm{LT}_{50}=10 \mathrm{~min}$ ) compared to Yang et al. [62], who observed an $\mathrm{LT}_{50}$ of $18.80 \mathrm{~min}$ at the $0.25 \mathrm{mg} / \mathrm{cm}^{2}$ concentration of the same oil.

Solvent: Essential oils are often dissolved in various solvents such as acetone [62], alcohol [106], ethylhexyl stearate [55], poloxamer [108], and mineral and vegetable oils [56]. However, certain solvents could influence the pediculicidal activity. For example, it has been demonstrated that ethanol and other alcohols may exert their own toxicity on the tested lice [106]. Oily excipients have also been shown to exert toxicity on lice.

\section{Chemical composition (formulation)}

The chemical composition of a plant essential oil depends on several parameters, most important of which are the environmental conditions.

Geographical variation: Essential oils derived from the same plant species originating from different geographical areas may 
have similar or radically different chemical compositions due to the climatic and soil variability [109] and can vary from year to year. For example, in bioassays tested using the same method (filter paper) and concentration, Yones et al. [40] and Gutiérrez et al. [51] observed different $\mathrm{LT}_{50}$ for $T$. vulgaris essential oils. The differences in their results were attributed to the difference in the chemical composition of plants originating from two different geographical areas, namely, Argentina and Egypt ( $\triangleright$ Table 1). Even within the same country, the chemical composition of essential oil obtained from the same plant species collected from two different locations may vary greatly. This was demonstrated by the main components of essential oils obtained from $S$. areira collected from different locations in Argentina being different $(\alpha$ pinene, $\beta$-pinene, T-cadinol, and limonene stated by Toloza et al. [67] compared to $\alpha$-pinene, camphene, myrcene, $\alpha$-phellandrene, and limonene reported by Gutiérrez et al. [51]). Another study demonstrated different pediculicidal activities of two chemotypes of Chenopodium ambrosioides, wherein chemotype (1) had a $\mathrm{KT}_{50}$ of $42 \mathrm{~min}$ while chemotype (2) was ineffective with a $\mathrm{KT}_{50}>60 \mathrm{~min}$ [110]. The differences in efficacy of these two chemotypes were attributed to variations in chemical composition; C. ambrosioides (1) had trans-carveol, trans-pinocarvyl acetate, and cis-carveol as main components, while C. ambrosioides (2) had ascaridole as its main component [50].

\section{Discussion}

Insecticides such as organochlorine, pyrethroid, and carbamate were introduced in the 20th century as treatments for pediculosis. They initially displayed high efficacy in killing lice. However, the repeated use of these chemicals resulted in the development of resistance among louse populations globally $[14,54]$, which posed a major challenge in the treatment of pediculosis. During the last decade, efforts have focused on developing new methods or formulations that are efficient against lice. These efforts have included exploring the potential of essential oils in the treatment of pediculosis. Numerous essential oils have been shown to be effective in eliminating lice. In the present study, we have conducted an exhaustive review of 172 research articles, books, and theses in order to evaluate the advantages and limitations of each group of essential oils in detail, and ultimately demonstrate the most effective ones against lice.

At present, there is no definitive and absolute treatment for pediculosis [111-113]. The use of essential oils derived from plants could have some benefits. A possible advantage of essential oils over some conventional insecticide treatments may be their ovicidal activity, which is seen in most of the oils discussed above $[40,51,55,62,114]$. Compounds with ovicidal effects may be particularly beneficial in the control of pediculosis, as they would eliminate the need for multiple treatments to kill newly hatched nymphs. Another advantage of essential oils is their activity on insecticide-resistant lice $[50,76,106]$.

Based on the published literature, the modes of evaluation and properties of the oils used in research investigations vary widely, leading to differences in results. Several factors may influence the rate of efficacy of essential oils. One such factor is the method applied to test the essential oil against louse species. Different methods involve different ways of exposure and biological availability of the active component of the oils [106]. For example, Eucalyptus oil was 50-fold more active in contact assays carried out in closed containers compared to open ones, possibly due to the fumigation action and vapor pressure [36]. Similarly, Toloza et al. [34] reported high fumigant activity of eucalyptus oil and its major component against head lice. In contrast, A. polystachya and $T$. vulgaris were considerably more effective through filter paper contact than fumigation ( $\vee$ Table 1 ) [51]. Differences in efficacy between these methods could be attributed to the efficacy of the mode of absorption (penetration) of the active constituent by the lice, which depends on the vapor pressure, density, viscosity, and lipophilicity of the essential oil constituents [40,51,67, 106]. Lipophilic and viscous compounds might perform better in contact bioassays because they can directly penetrate the cuticular layer of the lice [106]. In the fumigation assay, the components may be inhaled via the respiratory system, which depends on the vapor pressure of the compound [106]. These factors influence the eventual mode of action of essential oils on human lice.

Apart from the method, factors such as the concentration used, exposure time, main constituents, and the origin of the essential oils may also influence the results. The incorporation of solvents to solubilize essential oils is an important factor because certain solvents (e.g., alcohol) could enhance or diminish the pediculicidal activity of the formulation [50]. The presence of alcohol as a solvent in the formulation of tea tree oil (M. alternifolia) makes it difficult to confirm whether the observed pediculicidal effect is attributable to the tea tree oil or the solvent used [13]. Therefore, a neutral solvent can be added to the experiments as a control. In addition, other constituents in minor quantities may also have a possible synergistic or antagonistic activity $[41,107]$. Among the 22 genera of essential oils discussed above, which were reported to have pediculicidal activities, certain genera such as Aloysia, Cinnamomum, Eucalyptus, Eugenia, Lavandula, Melaleuca, Mentha, Myrcianthes, Origanum, Pimpinella, and Thymus have demonstrated high efficacy in killing the lice, which makes them strong candidates for clinical assays [23, 115-117]. Some major components of these plants belong to mono-oxygenated classes (1,8-cineole, linalool, pulegone, terpinen-4-ol, thymol), phenylpropanoids (anethole, cinnamaldehyde, eugenol), and monoterpene hydrocarbons ( $p$-cymene, limonene) ( $\triangleright$ Table 1$)$. Most of these components exert neurotoxic effects on insects. Their neurotoxic effects involve several mechanisms, in particular, via GABA and octopamine synapses, and the inhibition of acetylcholinesterase [118-121].

Furthermore, some essential oils, although highly effective against lice, cannot be directly formulated as pediculicidal products. Despite the high efficacy of some of these oils, their application has been restricted or banned due to high toxicity or objectionable odor $[22,122,123]$. Essential oils are environmentally safer because they are not persistent [122], but some have been shown to have high mammalian toxicity and may cause skin irritation $[123,124]$. However, in terms of mammalian toxicology, just the fact that a product is naturally occurring does not necessarily make it safe. On the other hand, the concentrations of essential oils used in the ex vivo bioassays are quite low (generally below $5 \%$, mostly even below $1 \%$ ), whereas the essential oil-based prod- 
ucts for the treatment of lice infestations typically contain at least $10 \%$ essential oil, which is around the threshold level of the concentration capable of causing vesicant reactions on human skin [110]. A clinical trial of a pediculicide containing more $>10 \%$ of eucalyptus essential oils plus $1 \%$ Leptospermum petersonii demonstrated satisfactory results [125]. In addition, some essential oils (e.g., M. pulegium, S. officinalis) and their compounds (e.g., pulegone, carvacrol, thujone, camphor, and menthol belonging to the chemical families of ketones and phenols) can be mildly to severely toxic to mammals. They often exert irritant, allergic, analgesic, or hepatotoxic, abortifacient, and hormone-like effects [123-129].

\section{Conclusion}

In the search for alternative nonchemical insecticides to be used in the treatment of pediculosis, some essential oils have been demonstrated to be as effective as traditional insecticides against $P$. humanus. In this review, 22 plant genera demonstrating effective in vitro pediculicidal activities were discussed. Among them, genera such as Aloysia, Cinnamomum, Eucalyptus, Eugenia, Lavandula, Melaleuca, Mentha, Myrcianthes, Origanum, Pimpinella, and Thymus appear to be more efficient. These genera are rich in anethole, 1,8-cineole, cinnamaldehyde, p-cymene, eugenol, linalool, limonene, pulegone, terpinen-4-ol, and thymol compounds. Current information indicates that the majority of the essential oils are safe to the users and environment, with few exceptions. Therefore, essential oils have immense potential to substitute synthetic insecticides, the use of which has generated resistance and toxicity problems. However, each essential oil must be evaluated for its potential threat to human health due to the intrinsic allergenicity of some of their components.

\section{Supporting information}

An additional list including the names and characteristics of the major essential oils previously reported to be inefficient against louse ectoparasites according to the literature is given in Table 1S.

\section{Contributors' Statement}

Conception and design of the work: K.C., M. A., and A. I. Data collection: K.C., M.A., V.A., R.D., and C.B. Analysis and interpretation of the data: K.C., M.A., R.D., and A. I. Drafting of the manuscript: K.C., M.A., R.D., and A.I. Critical revision of the manuscript: M. A., R.D., C.B., A.I.

\section{Conflict of Interest}

The authors declare that they have no conflict of interest.

\section{References}

[1] Chosidow O. Scabies and pediculosis. Lancet 2000; 355: 819-826

[2] Veracx A, Raoult D. Biology and genetics of human head and body lice. Trend Parasitol 2012; 28: 563-571

[3] Bachman JA, Brennan PF, Patrick TB, Cole M. A world wide web-based health resource. Survey of Missouri school nurses to determine priority health information resources for SchoolhealthLink. J Sch Nurs 2000; 16 : 28-33

[4] Gratz NG. Human lice. Their prevalence, control and resistance to insecticides. Geneva WHO/CTD/WHOPES 1997; 957: 3-28

[5] Falagas ME, Matthaoui DK, Rafailidis PI, Panos G, Pappas G. Worldwide prevalence of head lice. Emerg Infect Dis 2008; 14: 1493-1494

[6] Raoult D, Roux $V$. The body louse as a vector of reemerging human diseases. Clin Infect Dis 1999; 29: 888-911

[7] Burgess IF. Current treatments for pediculosis capitis. Curr Opin Infect Dis 2009; 22: 131-136

[8] Durand R, Bouvresse S, Berdjanea Z, Izri A, Chosidow O, Clarkc JM. Insecticide resistance in head lice: clinical, parasitological and genetic aspects. Clin Microbiol Infect 2012; 18: 338-344

[9] Koch E, Clark JM, Cohen B, Meinking TL, Ryan WG, Stevenson A, Yetman $\mathrm{R}$, Yoon KS. Management of head louse infestations in the United States - a literature review. Pediatr Dermatol 2016; 33: 466-472

[10] Sangaré AK, Doumbo OK, Raoult D. Management and treatment of human lice. Biomed Res Int 2016; 2016: 8962685

[11] Webber E, McConnell S. Lice update: management and treatment in the home. Home Healthc Now 2018; 36: 289-294

[12] Chosidow O, Chastang C, Brue C, Bouvet E, Izri M, Monteny N, BastujiGarin S, Rousset J], Revuz J. Controlled study of malathion and d-phenothrin lotions for Pediculus humanus var capitis-infested schoolchildren. Lancet 1994; 344: 1724-1727

[13] Downs AM, Stafford KA, Coles GC. Monoterpenoids and tetralin as pediculocides. Acta Derm Venereol 2000; 80: 69-70

[14] Kristensen M, Knorr M, Rasmussen AM, Jespersen JB. Survey of permethrin and malathion resistance in human head lice populations from Denmark. J Med Entomol 2006; 43: 533-538

[15] Burgess IF. The mode of action of dimeticone $4 \%$ lotion against head lice, Pediculus capitis. BMC Pharmacol 2009; 9: 3

[16] Meinking TL, Villar ME, Vicaria M, Eyerdam DH, Paquet D, Mertz-Rivera K, Rivera HF, Hiriart J, Reyna S. The clinical trials supporting benzyl alcohol lotion 5\% (Ulesfia): a safe and effective topical treatment for head lice (pediculosis humanus capitis). Pediatric Dermatol 2010; 27: 19-24

[17] Chosidow O, Giraudeau B, Cottrell J, Izri A, Hofmann R, Mann SG, Burgess I. Oral ivermectin versus malathion lotion for difficult-to-treat head lice. NEJM 2010; 362: 896-905

[18] Sangaré AK, Rolain JM, Gaudart ], Weber P, Raoult D. Synergistic activity of antibiotics combined with ivermectin to kill body lice. Int J Antimicrob Agents 2016; 47: 217-223

[19] Heukelbach J, Speare R, Canyon D. Natural products and their application to the control of head lice: An evidence-based review. Recent Trend Develop 2006; 1: 277-302

[20] Benelli G, Pavela R. Beyond mosquitoes-Essential oil toxicity and repellency against bloodsucking insects. Ind Crops Prod 2018; 117: 382-392

[21] Bakkali F, Averbeck S, Averbeck D, Idaomar M. Biological effects of essential oils - a review. Food Chem Toxicol 2008; 46: 446-475

[22] Regnault-Roger C, Vincent C, Arnason JT. Essential oils in insect control: low-risk products in a high-stakes world. Ann Rev Entomol 2012; 57 : 405-424

[23] Greive KA, Barnes TM. The efficacy of Australian essential oils for the treatment of head lice infestation in children: A randomised controlled trial. Australas J Dermatol 2018; 59: e99-e105

[24] Lesage-Meessen L, Bou M, Sigoillot JC, Faulds CB, Lomascolo A. Essential oils and distilled straws of lavender and lavandin: a review of current use and potential application in white biotechnology. Appl Microbiol Biotechnol 2015; 99: 3375-3385

[25] Cavanagh HM, Wilkinson JM. Biological activities of lavender essential oil. Phytother Res 2002; 16: 301-308 
[26] Valnet ]. The Practice of Aromatherapy: A classic Compendium of Plant Medicines \& their healing Properties. Rochester, NY: Healing Arts Press; 1990

[27] Lawless ]. Encyclopaedia of essential Oils. London: Element; 1992

[28] Gonzalez-Audino P, Picollo MI, Gallardo A, Toloza A, Vassena C, Mougabure-Cueto G. Comparative toxicity of oxygenated monoterpenoids in experimental hydroalcoholic lotions to permethrin-resistant adult head lice. Arch Dermatol Res 2011; 303: 361-366

[29] Pohlit AM, Lopes NP, Gama RA, Tadei WP, Neto VF. Patent literature on mosquito repellent inventions which contain plant essential oils - a review. Planta Med 2011; 77: 598-617

[30] Nechita IS, Poirel MT, Cozma V, Zenner L. The repellent and persistent toxic effects of essential oils against the poultry red mite, Dermanyssus gallinae. Vet Parasitol 2015; 214: 348-352

[31] Dhakad AK, Pandey VV, Beg S, Rawat JM, Singh A. Biological, medicinal and toxicological significance of Eucalyptus leaf essential oil: a review. J Sci Food Agric 2018; 98: 833-848

[32] Yang YC, Choi HY, Choi WS, Clark JM, Ahn YJ. Ovicidal and adulticidal activity of Eucalyptus globulus leaf oil terpenoids against Pediculus humanus capitis (Anoplura: Pediculidae). J Agricul Food Chem 2004; 52: 25072511

[33] Choi HY, Yang YC, Lee SH, Clark JM, Ahn YJ. Efficacy of spray formulations containing binary mixtures of clove and eucalyptus oils against susceptible and pyrethroid/malathion-resistant head lice (Anoplura: Pediculidae). J Med Entomol 2010; 47: 387-391

[34] Toloza AC, Lucia A, Zerba E, Masuh H, Picollo MI. Interspecific hybridization of Eucalyptus as a potential tool to improve the bioactivity of essential oils against permethrin-resistant head lice from Argentina. Bioresour Technol 2008; 99: 7341-7347

[35] Carroll SP, Loye J. PMD, a registered botanical mosquito repellent with deet-like efficacy. J Am Mosq Control Assoc 2006; 22: 507-513

[36] Yang YC, Lee HS, Clark JM, Ahn YJ. Insecticidal activity of plant essential oils against Pediculus humanus capitis (Anoplura: Pediculidae). I Med Entomol 2004; 41: 699-704

[37] Rao PV, Gan SH. Cinnamon: a multifaceted medicinal plant. Evid Based Complement Alternat Med 2014; 2014: 642942

[38] Veal L. The potential effectiveness of essential oils as a treatment for head lice, Pediculus humanus capitis. Complement Ther Nurs Midwifery 1996; 2: 97-101

[39] Yang YC, Lee HS, Lee SH, Clark JM, Ahn YJ. Ovicidal and adulticidal activities of Cinnamomum zeylanicum bark essential oil compounds and related compounds against Pediculus humanus capitis (Anoplura: Pediculicidae). Int J Parasitol 2005; 35: 1595-1600

[40] Yones DA, Bakir HY, Bayoumi SA. Chemical composition and efficacy of some selected plant oils against Pediculus humanus capitis in vitro. Parasitol Res 2016; 115: 3209-3218

[41] Deletre E, Chandre F, Williams L, Duménil C, Menut C, Martin T. Electrophysiological and behavioral characterization of bioactive compounds of the Thymus vulgaris, Cymbopogon winterianus, Cuminum cyminum and Cinnamomum zeylanicum essential oils against Anopheles gambiae and prospects for their use as bed net treatments. Parasit Vectors 2015; 8: 316

[42] Mimica-Dukic N, Bozin B. Mentha L. species (Lamiaceae) as promising sources of bioactive secondary metabolites. Curr Pharm Des 2008; 14 : 3141-3150

[43] El-Seedi HR, Khalil NS, Azeem M, Taher EA, Göransson U, Pålsson K, Borg-Karlson AK. Chemical composition and repellency of essential oils from four medicinal plants against Ixodes ricinus nymphs (Acari: Ixodidae). J Med Entomol 2012; 49: 1067-1075

[44] Yang JY, Kim MG, Lee SE, Lee HS. Acaricidal activities against house dust mites of spearmint oil and its constituents. Planta Med 2014; 80: 165170
[45] Buleandra M, Oprea E, Popa DE, David IG, Moldovan Z, Mihai I, Badea IA. Comparative chemical analysis of Mentha piperita and M. spicata and a fast assessment of commercial peppermint teas. Nat Prod Commun 2016; 11: 551-555

[46] Buchwald-Werner S, Naka I, Wilhelm M, Schütz E, Schoen C, Reule C. Effects of lemon verbena extract (Recoverben ${ }^{\circledR}$ ) supplementation on muscle strength and recovery after exhaustive exercise: a randomized, placebo-controlled trial. J Int Soc Sports Nutr 2018; 15: 5

[47] Werdin González JO, Gutiérrez MM, Murray AP, Ferrero AA. Biological activity of essential oils from Aloysia polystachya and Aloysia citriodora (Verbenaceae) against the soybean pest Nezara viridula (Hemiptera: Pentatomidae). Nat Prod Commun 2010; 5: 301-306

[48] Benelli G, Pavela R, Canale A, Cianfaglione K, Ciaschetti G, Conti F, Nicoletti M, Senthil-Nathan S, Mehlhorn H, Maggi F. Acute larvicidal toxicity of five essential oils (Pinus nigra, Hyssopus officinalis, Satureja montana, Aloysia citrodora and Pelargonium graveolens) against the filariasis vector Culex quinquefasciatus: Synergistic and antagonistic effects. Parasitol Int 2017; 66: 166-171

[49] Garcia MCF, Soares DC, Santana RC, Saraiva EM, Siani AC, Ramos MFS, Danelli MDGM, Souto-Padron TC, Pinto-da-Silva LH. The in vitro antileishmanial activity of essential oil from Aloysia gratissima and guaiol, its major sesquiterpene against Leishmania amazonensis. Parasitol 2018; 21: 1-9

[50] Toloza AC, Zygadlo J, Biurrun F, Rotman A, Picollo MI. Bioactivity of Argentinean essential oils against permethrin-resistant head lice, Pediculus humanus capitis. J Insect Sci 2010; 10: 185

[51] Gutiérrez MM, Werdin-González JO, Stefanazzi N, Bras C, Ferrero AA. The potential application of plant essential oils to control Pediculus humanus capitis (Anoplura: Pediculidae). Parasitol Res 2016; 115: 633-641

[52] Williamson EM, Priestley CM, Burgess IF. An investigation and comparison of the bioactivity of selected essential oils on human lice and house dust mites. Fitoterapia 2007; 78: 521-525

[53] Fang F, Candy K, Melloul E, Bernigaud C, Chai L, Darmon C, Durand R, Botterel F, Chosidow O, Izri A, Huang W, Guillot J. In vitro activity of ten essential oils against Sarcoptes scabiei. Parasite Vectors 2016; 9: 594

[54] Downs AMR, Stafford KA, Ravenscroff JC, Coles GC. Widespread insecticide resistance in head lice to the over-the-counter pediculocides in England, and the emergence of carbaryl resistance. British J Dermatol 2002; 146: 88-93

[55] Di Campli E, Di Bartolomeo S, Delli Pizzi P, Di Giulio M, Grande R, Nostro A, Cellini L. Activity of tea tree oil and nerolidol alone or in combination against Pediculus capitis (head lice) and its eggs. Parasitol Res 2012; 111: 1985-1992

[56] Candy K, Nicolas P, Andriantsoanirin V, Izri A, Durand R. In vitro efficacy of five essential oils against Pediculus humanus capitis. Parasitol Res 2018; 117: 603-609

[57] Orav A, Raal A, Arak E. Essential oil composition of Pimpinella anisum L. fruits from various European countries. Nat Prod Res 2008; 22: 227-232

[58] Khater HF, Hanafy A, Abdel-Mageed AD, Ramadan MY, El-Madawy RS. Control of the myiasis-producing fly, Lucilia sericata, with Egyptian essential oils. Int J Dermatol 2011; 50: 187-194

[59] Kimbaris AC, Koliopoulos G, Michaelakis A, Konstantopoulou MA. Bioactivity of Dianthus caryophyllus, Lepidium sativum, Pimpinella anisum, and Illicium verum essential oils and their major components against the West Nile vector Culex pipiens. Parasitol Res 2012; 111: 2403-2410

[60] Shojaii A, Abdollahi Fard M. Review of pharmacological properties and chemical constituents of Pimpinella anisum. ISRN Pharmacol 2012; 2012: 510795

[61] Chaieb K, Hajlaoui H, Zmantar T, Kahla-Nakbi AB, Rouabhia M, Mahdouani K, Bakhrouf A. The chemical composition and biological activity of clove essential oil, Eugenia caryophyllata (Syzigium aromaticum L. Myrtaceae): a short review. Phytotherap Res 2007; 21: 501-506 
[62] Yang YC, Lee SH, Lee W], Choi DH, Ahn Y]. Ovicidal and adulticidal effects of Eugenia caryophyllata bud and leaf oil compounds on Pediculus capitis. J Agricul Food Chemis 2003; 51: 4884-4888

[63] Pasay C, Mounsey K, Stevenson G, Davis R, Arlian L, Morgan M, Vyszenski-Moher D, Andrews K, McCarthy J. Acaricidal activity of eugenol based compounds against scabies mites. PLoS One 2010; 5: e12079

[64] Bras C, Gumilar F, Gandini N, Minetti A, Ferrero A. Evaluation of the acute dermal exposure of the ethanolic and hexanic extracts from leaves of Schinus molle var. areira L. in rats. J Ethnopharmacol 2011; 137: 14501456

[65] Martins Mdo R, Arantes S, Candeias F, Tinoco MT, Cruz-Morais ]. Antioxidant, antimicrobial and toxicological properties of Schinus molle L. essential oils. J Ethnopharmacol 2014; 151: 485-492

[66] Descamps LR, Sánchez Chopa C, Ferrero AA. Activity of Schinus areira (Anacardiaceae) essential oils against the grain storage pest Tribolium castaneum. Nat Prod Commun 2011; 6: 887-891

[67] Toloza AC, Zygadlo J, Cueto GM, Biurrun F, Zerba E, Picollo MI. Fumigant and repellent properties of essential oils and component compounds against permethrin-resistant Pediculus humanus capitis (Anoplura: Pediculidae) from Argentina. J Med Entomol 2006; 43: 889-895

[68] Cestari IM, Sarti SI, Waib CM, Branco AC. Evaluation of the potential insecticide activity of Tagetes minuta (Asteraceae) essential oil against the head lice Pediculus humanus capitis (Phthiraptera: Pediculidae). Neotrop Entomol 2004; 33: 805-807

[69] Perich MJ, Wells C, Bertsch W, Tredway KE. Toxicity of extracts from three Tagetes against adults and larvae of yellow fever mosquito and Anopheles stephensi (Diptera: Culicidae). J Med Entomol 1994; 31: 833837

[70] Politi FA, Nascimento JD, da Silva AA, Moro I], Garcia ML, Guido RV, Pietro RC, Godinho AF, Furlan M. Insecticidal activity of an essential oil of Tagetes patula L. (Asteraceae) on common bed bug Cimex lectularius L. and molecular docking of major compounds at the catalytic site of CIAChE1. Parasitol Res 2017; 116: 415-424

[71] Kimutai A, Ngeiywa M, Mulaa M, Njagi PG, Ingonga J, Nyamwamu LB, Ombati C, Ngumbi P. Repellent effects of the essential oils of Cymbopogon citratus and Tagetes minuta on the sandfly, Phlebotomus duboscqi. BMC Res Notes 2017; 10: 98

[72] Gakuubi MM, Wagacha JM, Dossaji SF, Wanzala W. Chemical composition and antibacterial activity of essential oils of Tagetes minuta (Asteraceae) against selected plant pathogenic bacteria. Int J Microbiol 2016; 2016: 7352509

[73] Bais S, Gill NS, Rana N, Shandil S. A phytopharmacological review on a medicinal plant: Juniperus communis. Int Sch Res Notices 2014; 2014: 634723

[74] Parvizi MM, Handjani F, Moein M, Hatam G, Nimrouzi M, Hassanzadeh J, Hamidizadeh N, Khorrami HR, Zarshenas MM. Efficacy of cryotherapy plus topical Juniperus excelsa M. Bieb cream versus cryotherapy plus placebo in the treatment of Old World cutaneous leishmaniasis: A triple-blind randomized controlled clinical trial. PLoS Neg Trop Dis 2017; 11: e0005957

[75] Kim JR, Perumalsamy H, Shin HM, Lee SG, Ahn YJ. Toxicity of Juniperus oxycedrus oil constituents and related compounds and the efficacy of oil spray formulations to Dermatophagoides farinae (Acari: Pyroglyphidae). Exp Appl Acarol 2017; 73: 385-399

[76] Yang YC, Lee SH, Clark JM, Ahn Y]. Ovicidal and adulticidal activities of Origanum majorana essential oil constituents against insecticide-susceptible and pyrethroid/malathion-resistant Pediculus humanus capitis (Anoplura: Pediculidae). J Agricul Food Chemis 2009; 57: 2282-2287

[77] Govindarajan M, Rajeswary M, Hoti SL, Benelli G. Larvicidal potential of carvacrol and terpinen-4-ol from the essential oil of Origanum vulgare (Lamiaceae) against Anopheles stephensi, Anopheles subpictus, Culex quinquefasciatus and Culex tritaeniorhynchus (Diptera: Culicidae). Res Vet Sci 2016; 104: 77-82
[78] Muturi EJ, Ramirez JL, Doll KM, Bowman M]. Combined toxicity of three essential oils against Aedes aegypti (Diptera: Culicidae) larvae. J Med Entomol 2017; 54: 1684-1691

[79] Shang X, Wang Y, Zhou X, Guo X, Dong S, Wang D, Zhang J, Pan H, Zhang Y, Miao X. Acaricidal activity of oregano oil and its major component, carvacrol, thymol and p-cymene against Psoroptes cuniculi in vitro and in vivo. Vet Parasitol 2016; 226: 93-96

[80] Park BS, Choi WS, Kim JH, Kim KH, Lee SE. Monoterpenes from thyme (Thymus vulgaris) as potential mosquito repellents. J Am Mosq Control Assoc 2005; 21: 80-83

[81] Pavela R, Vrchotová N, Tríska J. Mosquitocidal activities of thyme oils (Thymus vulgaris L.) against Culex quinquefasciatus (Diptera: Culicidae). Parasitol Res 2009; 105: 1365-1370

[82] Ebadollahi A, Sendi J], Aliakbar A. Efficacy of Nanoencapsulated Thymus eriocalyx and Thymus kotschyanus Essential Oils by a Mesoporous Material MCM-41 Against Tetranychus urticae (Acari: Tetranychidae). J Econom Entomol 2017; 110: 2413-2420

[83] Gaire S, O'Connell M, Holguin FO, Amatya A, Bundy S, Romero A Insecticidal properties of essential oils and some of their constituents on the Turkestan cockroach (Blattodea: Blattidae). J Econom Entomol 2017; 110: 584-592

[84] Rawat S, Jugran AK, Bhatt ID, Rawal RS. Hedychium spicatum: a systematic review on traditional uses, phytochemistry, pharmacology and future prospectus. J Pharm Pharmacol 2018; 70: 687-712

[85] Sakhanokho HF, Sampson B], Tabanca N, Wedge DE, Demirci B, Baser KH, Bernier UR, Tsikolia M, Agramonte NM, Becnel J], Chen J, Rajasekaran $\mathrm{K}$, Spiers JM. Chemical composition, antifungal and insecticidal activities of Hedychium essential oils. Molecule 2013; 18: 4308-4327

[86] Jadhav V, Kore A, Kadam V]. In-vitro pediculicidal activity of Hedychium spicatum essential oil. Fitoterapia 2007; 78: 470-473

[87] Kim SI, Yi JH, Tak JH, Ahn YJ. Acaricidal activity of plant essential oils against Dermanyssus gallinae (Acari: Dermanyssidae). Vet Parasitol 2004; 120: 297-304

[88] Abbasipour H, Mahmoudvand M, Rastegar F, Hosseinpour MH. Fumigant toxicity and oviposition deterrency of the essential oil from cardamom, Elettaria cardamomum, against three stored-product insects. J Insect Sci 2011; $11: 165$

[89] Tyliszczak B, Drabczyk A, Kudłacik-Kramarczyk S, Grabowska B, Kędzierska M. Physicochemical properties and cytotoxicity of hydrogels based on Beetosan ${ }^{\circledR}$ containing sage and bee pollen. Acta Biochim Pol 2017; 64: 709-712

[90] Llurba-Montesino N, Schmidt T]. Salvia species as sources of natural products with antiprotozoal activity. Int J Mol Sci 2018; 19: E264

[91] Kayedi MH, Haghdoost AA, Salehnia A, Khamisabadi K. Evaluation of repellency effect of essential oils of Satureja khuzestanica (Carvacrol), Myrtus communis (Myrtle), Lavendula officinalis and Salvia sclarea using standard WHO repellency tests. J Arthropod Borne Dis 2013; 8: 60-68

[92] Bouyahya A, Et-Touys A, Bakri Y, Talbaui A, Fellah H, Abrini ], Dakka N. Chemical composition of Mentha pulegium and Rosmarinus officinalis essential oils and their antileishmanial, antibacterial and antioxidant activities. Microb Pathog 2017; 111: 41-49

[93] Waliwitiya R, Kennedy C], Lowenberger CA. Larvicidal and oviposition-altering activity of monoterpenoids, trans-anithole and rosemary oil to the yellow fever mosquito Aedes aegypti (Diptera: Culicidae). Pest Manag Sci 2009; 65: 241-248

[94] Kohn LK, Queiroga CL, Martini MC, Barata LE, Porto PS, Souza L, Arns CW. In vitro antiviral activity of Brazilian plants (Maytenus ilicifolia and Aniba rosaeodora) against bovine herpesvirus type 5 and avian metapneumovirus. Pharm Biol 2012; 50: 1269-1275

[95] Dos Santos ÉRQ, Maia CSF, Fontes Junior EA, Melo AS, Pinheiro BG, Maia JGS. Linalool-rich essential oils from the Amazon display antidepressant-type effect in rodents. J Ethnopharmacol 2018; 212: 43-49 
[96] Kong DG, Zhao Y, Li GH, Chen B], Wang XN, Zhou HL, Lou HX, Ren DM, Shen T. The genus Litsea in traditional Chinese medicine: an ethnomedical, phytochemical and pharmacological review. J Ethnopharmacol 2015; 164: 256-264

[97] Lin B, Sun LN, Xin HL, Nian H, Song HT, Jiang YP, Wei ZQ, Qin LP, Han T. Anti-inflammatory constituents from the root of Litsea cubeba in LPSinduced RAW 264.7 macrophages. Pharm Biol 2016; 54: 1741-1747

[98] Noosidum A, Prabaripai A, Chareonviriyaphap T, Chandrapatya A. Excito-repellency properties of essential oils from Melaleuca leucadendron L., Litsea cubeba (Lour.) Persoon, and Litsea salicifolia (Nees) on Aedes aegypti (L.) mosquitoes. J Vector Ecol 2008; 33: 305-312

[99] Seo SM, Kim J, Lee SG, Shin CH, Shin SC, Park IK. Fumigant antitermitic activity of plant essential oils and components from Ajowan (Trachyspermum ammi), Allspice (Pimenta dioica), caraway (Carum carvi), dill (Anethum graveolens), Geranium (Pelargonium graveolens), and Litsea (Litsea cubeba) oils against Japanese termite (Reticulitermes speratus Kolbe). J Agric Food Chem 2009; 57: 6596-6602

[100] Demo MS, Oliva MM, Zunino MP, Lopez ML, Zygadlo JA. Aromatic plants from Yungas. Part IV: Composition and antimicrobial activity of Myrcianthes pseudo-mato essential oil. Pharmaceutical Biol 2002; 40: 481-484

[101] Chavez Carvajal P, Coppo E, Di Lorenzo A, Gozzini D, Bracco F, Zanoni G, Nabavi SM, Marchese A, Arciola CR, Daglia M. Chemical characterization and in vitro antibacterial activity of Myrcianthes hallii (O. Berg) McVaugh (Myrtaceae), a traditional plant growing in Ecuador. Materials (Basel) 2016; 9: E454

[102] Dell'Agli M, Sanna C, Rubiolo P, Basilico N, Colombo E, Scaltrito MM, Ndiath MO, Maccarone L, Taramelli D, Bicchi C, Ballero M, Bosisio E. Anti-plasmodial and insecticidal activities of the essential oils of aromatic plants growing in the Mediterranean area. Malaria J 2012; 11 : 219

[103] Traboulsi AF, Taoubi K, el-Haj S, Bessiere JM, Rammal S. Insecticidal properties of essential plant oils against the mosquito Culex pipiens molestus (Diptera: Culicidae). Pest Management Sci 2002; 58: 491-495

[104] Oladimeji FA, Orafidiya OO, Ogunniyi TA, Adewunmi TA. Pediculocidal and scabicidal properties of Lippia multiflora essential oil. J Ethnopharmacol 2000; 72: 305-311

[105] Valentin A, Pélissier Y, Benoit F, Marion C, Kone D, Mallie M, Bastide JM, Bessière JM. Composition and antimalarial activity in vitro of volatile components of Lippia multiflora. Phytochemistry 1995; 40: 1439-1442

[106] Gonzalez-Audino P, Vassena C, Zerba E, Picollo M. Effectiveness of lotions based on essential oils from aromatic plants against permethrin resistant Pediculus humanus capitis. Arch Dermatol Res 2007; 299: 389-392

[107] Gallardo A, Picollo MI, González-Audino P, Mougabure-Cueto G. Insecticidal activity of individual and mixed monoterpenoids of geranium essential oil against Pediculus humanus capitis (Phthiraptera: Pediculidae). J Med Entomol 2012; 49: 332-335

[108] Lucia A, Toloza AC, Guzmán E, Ortega F, Rubio RG. Novel polymeric micelles for insect pest control: encapsulation of essential oil monoterpenes inside a triblock copolymer shell for head lice control. Peer] 2017; 5: e3171

[109] Thompson JD, Chalchat JC, Michet A, Linhart YB, Ehlers B. Qualitative and quantitative variation in monoterpene co-occurrence and composition in the essential oil of Thymus vulgaris chemotypes. J Chem Ecol 2003; 29: 859-880

[110] Toloza AC, Zygadlo ], Biurrun F, Rotman A, Picollo MI. Bioactivity of Argentinean essential oils against permethrin-resistant head lice, Pediculus humanus capitis. J Insect Sci 2010; 10: 185

[111] Abdel-Ghaffar F, Abdel-Aty M, Rizk I, Al-Quraishy S, Semmler M, Gestmann F, Hoff NP. Head lice in progress: what could/should be done-a report on an in vivo and in vitro field study. Parasitol Res 2016; 115: 4245-4249

[112] Burgess IF, Silverston P. Head lice. BM] Clin Evid 2015; 1: 1703

[113] Feldmeier $\mathrm{H}$. Treatment of pediculosis capitis: a critical appraisal of the current literature. Am J Clin Dermatol 2014; 15: 401-412

[114] Toloza AC, Vassena C, Picollo MI. Ovicidal and adulticidal effects of monoterpenoids against permethrin-resistant human head lice, Pediculus humanus capitis. Med Vet Entomol 2008; 22: 335-339

[115] Barker SC, Altman PM. A randomised, assessor blind, parallel group comparative efficacy trial of three products for the treatment of head lice in children-melaleuca oil and lavender oil, pyrethrins and piperonyl butoxide, and a "suffocation" product. BMC Dermatol 2010; 10 : 6

[116] Barker SC, Altman PM. An ex vivo, assessor blind, randomized, parallel group, comparative efficacy trial of the ovicidal activity of three pediculicides after a single application-melaleuca oil and lavender oil, eucalyptus oil and lemon tea tree oil, and a "suffocation" pediculicide. BMC Dermatol 2011; 11: 14

[117] Burgess IF, Brunton ER, Burgess NA. Clinical trial showing superiority of a coconut and anise spray over permethrin $0.43 \%$ lotion for head louse infestation. Eur J Pediatr 2010; 169: 55-62

[118] Enan E. Insecticidal activity of essential oils: octopaminergic sites of action. Comp Biochem Physiol C Toxicol Pharmacol 2001; 130: 325337

[119] Enan EE. Molecular and pharmacological analysis of an octopamine receptor from American cockroach and fruit fly in response to plant essential oils. Arch Insect Bioch Physiol 2005; 59: 161-171

[120] Priestley CM, Williamson EM, Wafford KA, Sattelle DB. Thymol, a constituent of thyme essential oil, is a positive allosteric modulator of human $\mathrm{GABA}(\mathrm{A})$ receptors and a homo-oligomeric GABA receptor from Drosophila melanogaster. British J Pharmacol 2003; 140: 1363-1372

[121] Picollo MI, Toloza AC, Mougabure-Cueto G, Zygadlo J, Zerba E. Anticholinesterase and pediculicidal activities of monoterpenoids. Fitoterapia 2008; 79: 271-278

[122] Mumcuoglu KY, Magdassi S, Miller J, Ben-Ishai F, Zentner G, Helbin V, Friger M, Kahana F, Ingber A. Repellency of citronella for head lice: double-blind randomized trial of efficacy and safety. Isr Med Assoc J 2004; 6: 756-759

[123] Radulović NS, Genčić MS, Stojanović NM, Randjelović PJ, StojanovićRadić ZZ, Stojiljković NI. Toxic essential oils. Part V: Behaviour modulating and toxic properties of thujones and thujone-containing essential oils of Salvia officinalis L., Artemisia absinthium L., Thuja occidentalis L. and Tanacetum vulgare L. Food Chem Toxicol 2017; 105: 355-369

[124] Gordon P, Khojasteh SC. A decades-long investigation of acute metabolism-based hepatotoxicity by herbal constituents: a case study of pennyroyal oil. Drug Metab Rev 2015; 47: 12-20

[125] Greive KA, Barnes TM. The efficacy of Australian essential oils for the treatment of head lice infestation in children: A randomised controlled trial. Australian J Dermatol 2017; 59: e99-e105

[126] Henley DV, Lipson N, Korach KS, Bloch CA. Prepubertal gynecomastia linked to lavender and tea tree oils. NEJM 2007; 356: 479-485

[127] Mathew T, Kamath V, Kumar RS, Srinivas M, Hareesh P, Jadav R, Swamy S. Eucalyptus oil inhalation-induced seizure: A novel, underrecognized, preventable cause of acute symptomatic seizure. Epilepsia Open 2017; 2: 350-354

[128] Halicioglu O, Astarcioglu G, Yaprak I, Aydinlioglu H. Toxicity of Salvia officinalis in a newborn and a child: an alarming report. Pediatr Neurol 2011; 45: 259-260

[129] Skalli S, Chebat A, Badrane N, Bencheikh RS. Side effects of cade oil in Morocco: an analysis of reports in the Moroccan herbal products database from 2004 to 2012. Food Chem Toxicol 2014; 64: 81-85 